\title{
DA PRÁtICA À PRODUÇão do CONHECIMENTO: BIBLIOTECAS E BIBLIOTECONOMIA PRÉ-CIENTÍFICA
}

\author{
FROM PRACTICE TO THE PRODUCTION OF KNOWLEDGE: \\ LIBRARIES AND PRE-SCIENTIFIC LIBRARY SCIENCE
}

DE LA PRÁCTICA HASTA LA PRODUCCIÓN DEL CONOCIMIENTO: BIBLIOTECAS Y BIBLIOTECONOMÍA PRE-CIENTÍFICA

Gabrielle Francinne Tanus ${ }^{1}$

${ }^{1}$ Universidade Federal do Rio Grande do Norte

Correspondência

${ }^{1}$ Gabrielle Francinne Tanus (D)

Universidade Federal do Rio Grande do Norte

Natal, RN

E-mail: gfrancinne@gmail.com

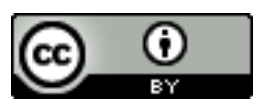

JITA: AA. Library and information science as a field.

Submetido em: 05/01/2018

Aceito em: 28/02/2018

Publicado em: 27/02/2018 
RESUMO: A indissociável relação entre as bibliotecas e a Biblioteconomia conduz a uma reconstituição da história dessas instituições, começando pelo período mais remoto, a Antiguidade. Momento este de nascimento da escrita, dos primeiros registros do conhecimento, e, por conseguinte, dos primeiros acervos. Tanto neste momento, quanto no posterior, a Idade Média, as práticas no ambiente da biblioteca antecedem as teorias ou estruturas de pensamento sistematizadas. $\mathrm{O}$ desejo em custodiar e conservar é comum tanto nas bibliotecas da Antiguidade como nas bibliotecas da Idade Média, o que possibilita uma aproximação desses distintos momentos sob a designação de uma Biblioteconomia pré-científica. Para tanto, convoca-se a partir de uma pesquisa bibliográfica diversos autores que abordam a história da biblioteca, particularmente, vinculada aqueles dois momentos. Acredita-se que, perscrutar este largo período da história e da qual a Biblioteconomia faz parte, possibilitaria uma maior compreensão da mesma, bem como de suas práticas exercidas nas bibliotecas, em especial, na Antiguidade e na Idade Média.

PALAVRAS-ChaVE: História da biblioteca. Biblioteconomia. Bibliotecário.

ABSTRACT: The inseparable relationship between libraries and Library Science leads to a reconstitution of the history of these institutions, starting with the earliest period, antiquity. This moment of writing birth of the first records of knowledge, and therefore the first collections. Both at this time and later in the Middle Ages, practices in the library environment precede systematized theories or structures of thought. The desire to guard and preserve is common in both the libraries of antiquity and in the libraries of the Middle Ages, which makes it possible to approximate these distinct moments under the name of a pre-scientific Library Science. For that, a bibliographical research is summoned by several authors who approach the history of the library, particularly, linked to those two moments. It is believed that to study this long period of history and of which Library Science is a part, would enable a greater understanding of Library Science, as well as their practices in libraries, especially in Antiquity and the Middle Ages.

KEYWORDS: History of library. Library Science. Librarian.

RESUMEN: La inseparable relación entre las bibliotecas y la Biblioteconomía conduce a una reconstitución de la historia de esas instituciones, empezando por el período más remoto, la Antigüedad. Momento este de nacimiento de la escritura, de los primeros registros del conocimiento, y, por consiguiente, de los primeros acervos. Tanto en este momento, como en el posterior, la Edad Media, las prácticas en el ambiente de la biblioteca anteceden a las teorías o estructuras de pensamiento sistematizadas. El deseo de custodiar y conservar es común tanto en las bibliotecas de la Antigüedad como en las bibliotecas de la Edad Media, lo que posibilita una aproximación de esos distintos momentos bajo la designación de una Biblioteconomía pre-científica. Para ello, se convoca a partir de una investigación bibliográfica diversos autores que abordan la historia de la biblioteca, particularmente, vinculada aquellos dos momentos. Se cree que, escrutar este largo período de la historia y de la que forma parte la Biblioteconomía, posibilitar una mayor comprensión de la misma, así como de sus prácticas ejercidas en las bibliotecas, especialmente en la Antigüedad y en la Edad Media.

PAlABRAS Clave: Historia de la biblioteca. Biblioteca. Bibliotecario.

\begin{tabular}{l|l} 
v.16 & n.3
\end{tabular}




\section{INTRODUÇÃ̃}

"Uma biblioteca nunca é alheia à sua época e esta se manifesta naquela pela ordem dos saberes que incita sua fundação" (GOULEMONT, 2011, p. 60).

A Biblioteconomia, em sua trajetória e compreensão, pode ser vista por meio de diferentes caminhos, mas a direção mais comum costuma-se iniciar pela explicação etimológica de sua palavra, passando, em seguida, pela história das bibliotecas, de seu ensino, de suas pesquisas, entre outros aspectos. $\mathrm{O}$ desenvolvimento da Biblioteconomia não se deu de modo igualitário em todos os países, em decorrência das diferenças das necessidades e dos próprios contextos históricos. A historicidade desses saberes biblioteconômicos possibilita compreender as diferentes visões acerca da biblioteca, do bibliotecário e da Biblioteconomia ao longo da história. Contudo, independente de seu desenvolvimento secular, a origem da Biblioteconomia tem uma arkhê comum, na qual se vincula a passagem de uma cultura oral para uma cultura escrita, o que impulsionou o surgimento dos suportes da escrita, e, por conseguinte, dos primeiros acervos das primeiras bibliotecas primitivas da Antiguidade.

Esse termo "primitivo" relaciona-se tanto com o fato cronológico, das primeiras bibliotecas existentes, como pela forma rudimentar do fazer, o qual era guiado pela prática, e não por um saber sistematizado teoricamente, ou seja, a ação decorria da necessidade imediata daquele momento antigo. Entre esses fazeres, na Antiguidade, estão as ações de organização e armazenamento dos registros do conhecimento, de tabuinhas a rolos de papiro e pergaminho, assim como as ações de preservação dos mesmos. Tais atividades de organização podem ser vistas como os primeiros princípios da Biblioteconomia. Para muitos autores da área, as bibliotecas da antiguidade constituem na própria gênese da Biblioteconomia, uma vez que a necessidade de sistematizar o conhecimento para os fins de organização, armazenamento, preservação e recuperação foram postos naquele momento (LINARES COLUMBIÉ, 2004; ORTEGA, 2004; TANUS, 2015). Os fazeres de modo empírico, sem uma reflexão teórica sistematizada que antecedesse a prática fazia parte dessa conjuntura, podendo chamar o campo de Biblioteconomia prática ou pré-científica (PULIDO; MORRILAS, 2010).

Considera-se, ainda, que essas práticas biblioteconômicas, mesmo que rudimentares, mas talvez avançadas para a época, constituem as primeiras ações e saberes, que viriam constituir séculos depois, o campo específico do conhecimento, a Biblioteconomia. Sobre a história das bibliotecas, no período seguinte à Antiguidade, a Idade Média, sabe-se que as bibliotecas não mudaram significativamente, mantendo-se suas portas fechadas aos poucos homens privilegiados, ou melhor, aos homens letrados (MARTINS, 2002). Contudo, de um espaço de investigação e de cultura como ocorria, em especial, na Biblioteca de Alexandria, na Antiguidade, as bibliotecas medievais passaram a ser conhecidas como extensões dos mosteiros, dos conventos, em geral, das ordens religiosas. O saber, antes de pretensão universal, encontrava-se no medievo recluso nos domínios do catolicismo e na língua latina.

n.3

p. $254-273$

set./dez. 2018 
Os fazeres de modo empírico ainda predominavam nesse momento, podendo chamar o campo de Biblioteconomia prática (ou pré-científica), tal qual era na Antiguidade.

Para Pulido e Morrilas (2010), a Biblioteconomia pode ser assim denominada por três momentos distintos, o primeiro nomeado de pré-científico, que vai da Antiguidade ao final da Idade Média; o segundo momento, de Biblioteconomia proto-científica que vai da Idade Moderna ao século XVIII; e o terceiro momento, inaugurado na Idade Contemporânea, no século XIX, nomeado de Biblioteconomia científica. A Idade Moderna teve como um dos marcos a imprensa dos tipos móveis, o que possibilitou a mudança da produção manual do livro para o impresso, e, com isso, uma maior circulação de livros e um aumento de leitores para além das Bíblias e do círculo religioso. O livro passa, então, a ser sentido como uma necessidade, a leitura e a escrita concomitantemente passam a ser requeridas e valorizadas. Contudo, vale a pena destacar, que a introdução dos livros impressos não foi imediata na sociedade, havia certo receio quanto à arte da impressão, assim muitos dos livros impressos traziam as características dos livros manuscritos (EISENSTEIN, 1998).

A expansão do Renascimento e da cultura laica despertou também a importância dos livros, aumentando as atividades de colecionadores, bibliófilos, e, consequentemente, um crescimento das bibliotecas particulares. Para a organização dos livros foram acentuadas certas atividades como produção de bibliografias, de catálogos e das classificações impressas. Nesse momento, destacam-se as ações de "bibliotecários" e filósofos a favor de bibliotecas abertas para todos e com coleções organizadas. Assim, as bibliotecas deixaram, paulatinamente, de serem vistas como meros depósitos dos registros, dando espaço a imagem da biblioteca como uma instituição capaz de disponibilizar os registros do conhecimento para os leitores, aliada a essa mudança está o aumento da complexidade do pensamento, da produção de obras específicas, que marca a configuração de uma Biblioteconomia protocientífica (TANUS, 2015).

Assim, passados esses dois momentos da Biblioteconomia, uma pré-científica e outra proto-científica, a Biblioteconomia inicia-se o caminho de uma Biblioteconomia científica, na Idade Contemporânea. Como efeito, é devido às transformações e consequências geradas pelas revoluções burguesas e industriais, que as bibliotecas tornam-se espaços públicos e abertos para a sociedade, para o povo, conduzindo a uma mudança na função social da biblioteca bem distinta de outros tempos, convocando a uma discussão cada vez mais intensa sobre a função das bibliotecas. No ramo científico a Biblioteconomia, por sua vez, parece seguir os caminhos das ciências exatas e naturais, com seus métodos e rigores científicos, tendo como forte influência o pensamento positivista (ARAÚJO, 2017). Inspirada naquelas ciências, o positivismo, primeira corrente de pensamento das Ciências Sociais e Humanas, iniciada no século XIX, por Augusto Comte, defendia também o rigor do método, da observação, da acumulação dos fatos, de uma realidade pronta e objetiva, afastando-se assim da teologia, da metafísica e de aspectos subjetivos. 
Enfim, esse longo percurso de séculos de história possibilita afirmar que as bibliotecas acompanham as mudanças de seu tempo e os diferentes contextos em que se inserem: social, político, econômico, cultural e científico. E, como qualquer outro trabalho que envolve levantamento bibliográfico, este texto requer um recorte para que seja exequível, portanto, adotou-se como foco abordar a história das bibliotecas na Antiguidade e na Idade Média, momento em que opera a classificação de Biblioteconomia pré-científica, conforme defendem Pulido e Morrilas (2010). Nessa direção, busca-se trazer mais acontecimentos relacionados com essa história, bem como demonstrar outras produções que fazem parte da construção de uma prática desenvolvida ao longo dos séculos, e que contribuem para a consolidação posteriormente da Biblioteconomia como campo científico, especificamente, no século XIX (TANUS, 2016).

Apesar da longa jornada das bibliotecas, Linares-Columbié (2004) ressalta que, reside uma lacuna na histórica da Biblioteconomia como espaço autônomo de conhecimento. As pesquisas sobre a produção da Biblioteconomia demonstram que prevalecem as preocupações com o universo empírico, pesquisas de cunho profissional, geralmente, quantitativas, as quais se voltam para o labor dentro do espaço da biblioteca, afastando-se de categorias abstratas e de pesquisas teóricas sobre o seu próprio campo. Assim, acredita-se que a exposição dos conhecimentos desenvolvidos sobre as bibliotecas e a partir delas, ainda que tais produções sejam remotas, é profícuo trazer à luz a fim de um maior entendimento acerca da historicidade das bibliotecas e da constituição da Biblioteconomia, ou mesmo quem sabe instigar a leitura na íntegra da produção do conhecimento ora identificada e apresentada.

\section{AS BIBLIOTECAS NA ANTIGUIDADE}

A biblioteca mais famosa desse período era a de Alexandria, cidade de mesmo nome que ficava na região norte do Egito, a oeste do rio Nilo e as margens do mediterrâneo, um espaço estratégico para o desenvolvimento da polis, fundada por Alexandre Magno, em 331 a.C. Sua localização privilegiada facilitava o contato com outros continentes (Europa, África e Ásia), por meio do porto e das rotas marítimas, o que possibilitava a entrada e a saída de pessoas, produtos, mercadorias, e, claro, muitos registros do conhecimento fruto da ação do homem em materializar suas ações. Além da localização de fácil entrada e saída, Alexandria constituía em um espaço fértil, devido à abundância de água, para o nascimento do principal suporte de escrita da época, o papiro', e o principal suporte da Biblioteca de Alexandria. Essa biblioteca, fundada no século III a.C, idealizada por Demétrio de Falera, durante a dinastia dos Ptolomeus, tinha como objetivo inicial preservar a obra de Aristóteles e competir com Atenas, cidade grega, capital cultural e intelectual daquele momento (FLOWER, 2002; MANGUEL, 2006).

Segundo Jacob (2000), Aristóteles (filósofo grego e preceptor de Alexandre, o Grande) foi o primeiro homem a ter reunido uma coleção de livros, collector librorum, e a ter ensinado aos reis do Egito uma maneira de organizar uma biblioteca em que a ordenação

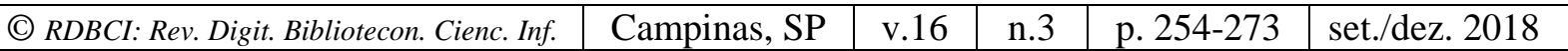


compreendia um projeto intelectual. Em pouco tempo a biblioteca alexandrina ampliou significativamente sua intenção, constituindo-se em uma "biblioteca universal" de todo o conhecimento registrado, o que lhe marcou o título de "Grande Biblioteca" ou "Pólo do saber do mundo ocidental" (CHAUI, 2010; FLOWER, 2002). Além da quantidade extraordinária de rolos de papiro, aproximadamente setecentos mil dos mais variados assuntos, a biblioteca era um centro de investigação científica, que abrigava sábios das letras, da geometria, trigonometria, astronomia e medicina (CHAUI, 2010). Nesse espaço híbrido, Biblioteca e Museu de Alexandria conviviam diversos estudiosos com os mais variados interesses, sobretudo, no que se refere ao desenvolvimento dos conhecimentos das ciências e da compreensão do mundo a sua volta.

O desejo de abarcar todo o conhecimento disponível (de várias línguas e de vários povos) em um único espaço fomentou diversos esforços em prol da ampliação do acervo dessa biblioteca, seja por meio da aquisição, da doação, da cópia ou mesmo pelo furto de livros de grande valor (JACOB, 2000). Flower (2002) relata que Ptolomeu I (Sóter) escreveu a todos os governantes dos quatro cantos do mundo solicitando que enviassem todos os tipos de obras (poesia, prosa, retórica, geografia, medicina, astronomia). Nesse primeiro momento, Fisher (2006) relata que os rolos de papiro eram armazenados em prateleiras colocadas em nichos que seguiam a extensão de uma ampla e coberta galeria. Essa preocupação em agrupar a totalidade do conhecimento humano, a fim de tornar a biblioteca uma espécie de memória do mundo, impulsionou a ascensão da palavra escrita e da expansão da cultura escrita. "Acima de tudo, a escrita tinha deixado de apenas documentar e preservar, passando a legitimar e validar o conhecimento" (FISCHER, 2006, p. 54).

Ptolomeu II (Filadelfo) era igualmente um "homem das letras" e prosseguiu com o desejo de reunir todo o conhecimento registrado e da constituição de um pólo irradiador da ciência e da cultura, atraindo mais estudiosos e adquirindo mais obras novas ou obras copiadas. Foi durante seu reinado que, setenta judeus em setenta e dois dias, traduziram a Bíblia do hebraico para o grego, ficando essa obra conhecida com "Versão dos Setenta" ou "Septuaginta". Já durante o reinado de Ptolomeu III (Evérgeta) "ninguém era capaz de ler todo conteúdo da biblioteca" (FISCHER, 2006, p. 54). Ademais, Ptolomeu III decretou uma medida suplementar, em que todo navio que aportasse em Alexandria deveria entregar seus livros para a cópia, ficando esses livros conhecidos como "livros de barco", os quais eram devolvidos muitas das vezes as cópias, ficando a biblioteca com os originais (FLOWER, 2002; CANFORA, 1989).

Assim, devido à extensão de seu acervo, a Biblioteca de Alexandria, dividia-se em "biblioteca-mãe" e em "biblioteca-filha", a primeira ficava junto ao Museion (templo das musas), no bairro do Brunchium, e a segunda, construída durante o governo de Ptolomeu III, no bairro de Serápio. Essa biblioteca abrigava as obras duplicadas da primeira biblioteca, bem como as obras saqueadas da Biblioteca de Pérgamo ${ }^{\mathrm{ii}}$, por Marco Antonio como presente para a rainha Cleópatra, sua amante. Embora essa biblioteca tenha sido marcada como um

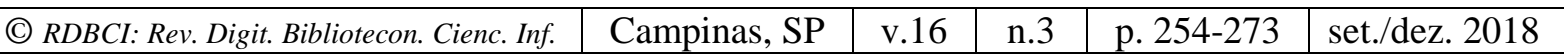


centro cultural e intelectual, onde diversos estudiosos de várias áreas do pensamento desenvolveram suas pesquisas, "a biblioteca não tinha como finalidade a difusão filantrópica e educativa do saber na sociedade, e sim a acumulação de todos os escritos da terra, no centro do palácio real" (JACOB, 2008), o que reforçava o papel da biblioteca como propriedade do Estado, cuja manutenção dependia do financiamento dos reis. Por essa razão, a biblioteca cresceu porque recebia justamente apoio real, como um ativo nacional institucionalizado (FISCHER, 2006).

Para Martins (2002) a biblioteca de Alexandria era igualmente célebre não só pelo seu número de volumes como também pela quantidade de desastres que sofrera ao longo dos anos. Em 48 a.C houve o primeiro incêndio acidental, ocasionado durante a permanência de Júlio César que, para impedir a comunicação marítima de seus inimigos, ateou fogo em seus navios, e que se expandiu até a biblioteca, queimando os volumes da primeira biblioteca. $\mathrm{O}$ segundo incêndio ocorreu em 272 d.C pelo imperador Aureliano, em guerra contra a rainha Zenóbia, que devastou a região do Brunchium, e a biblioteca filha, que ganhara importância após o primeiro incêndio. O terceiro incêndio, em 392 d.C, teve como alvo a biblioteca-filha, em Serápio, e foi provocado pelo imperador Teodósio I. O último e definitivo incêndio relaciona-se com a ocupação de Alexandria pelos muçulmanos, em 642 d.C, que conduziu de vez a derrocada da biblioteca com a queima dos livros, segundo a ordem de Califa Omar I (BASTOS, 2008).

Além dessas bibliotecas, outras instituições inclusive mais remotas, também fizeram parte desse período antigo, nas regiões da Babilônia, Mesopotâmia, Síria, Gaza, Grécia e Roma, somando no período de 1500 a.C a 3000 a.C, em pelo menos 51 cidades do Oriente Médio, mais de 233 arquivos e bibliotecas (BÁEZ, 2006). Vale lembrar que, arquivos e bibliotecas somente assumem contornos mais específicos na Idade Moderna, antes disso pode-se falar que os acervos formavam um desiderato comum, não havendo, portanto, uma separação institucional entre elas tal como hoje é conhecido (SILVA; RIBEIRO, 1999).

De qualquer forma, essas bibliotecas antecessoras da biblioteca de Alexandria ficaram conhecidas pelas milhares de tabuinhas de argila, suporte este que antecede ao papiro. Dentre as mais conhecidas estão a Biblioteca de Assurbanipal ou Biblioteca de Nínive, a Biblioteca de Ebla e a Biblioteca de Nippur. As tabuinhas tinham como finalidade materializar aquilo que era dito, a fala, por meio da palavra, da escrita cuneiforme imortal" (FISCHER, 2006). Para Jean (2008) "notas de compra e vendas não podem ser registradas oralmente, por essa razão tão prosaica nasceu a escrita". Assim, tais registros tinham, sobretudo, como finalidade "supervisionar e validar contas e contratos, bem como estimular a memória daqueles que lembravam a extensa história oral" (FISCHER, 2006, p. 13). Em suma, "mais de $75 \%$ das 150 mil inscrições cuneiformes escavadas até hoje na Mesopotâmia são registros contábeis e administrativos, e os mais antigos são essencialmente listas de produtos, pessoas, pagamentos etc" (FISCHER, 2006, p. 23).

n.3

p. $254-273 \quad$ set./dez. 2018 
O próprio formato e dimensão das tabuinhas exigiam que fossem feitos inscrições de textos curtos, informações objetivas e precisas, vinculadas às questões de trabalho, sejam elas administrativas ou econômicas das cidades, e não textos longos e contínuos como os registrados em papiro, em hieróglifos e hierática, da Biblioteca de Alexandria. A ampliação dos domínios das cidades-estado, de suas transações econômicas e administrativas, está também por sua vez, diretamente, ligada à necessidade crescente da palavra escrita, o que passou a exigir maneiras mais duráveis para documentar tais atividades. Essa codificação dos sinais, da escrita cuneiforme, era realizada apenas por um seleto grupo de pessoas, pois "pouquíssimas pessoas tinham motivos para aprender a ler: apenas os que desejassem conferir uma conta, verificar um rótulo ou identificar uma chancela de propriedade" (FISCHER, 2006, p. 13). A própria leitura dos textos estava condicionada à forma física do material, que se limitava a uma finalidade imediata e não de lazer.

Os escribas, além de escrever, ofício aprendido dos seis aos dezoito anos, vinte quatro dias em um período de trinta, cujo período ia do matutino ao vespertino, liam também para seus superiores ou senhores iletrados. Assim, pode-se dizer que grande parte do conhecimento social era difundido pela leitura oral, uma leitura que deveria ser lida para que os outros pudessem escutar o texto, portanto, "um escriba sumério, sem dúvida, tinha um grande senso de responsabilidade por possuir essa capacidade de extremo valor, sabendo que sua interpretação de um texto escrito encerraria uma discussão sobre contas ou um artigo de uma lei” (FISCHER, 2006, p. 19).

Dentre aquelas bibliotecas da Mesopotâmia citadas outrora está a Biblioteca de Nínive, que foi fundada entre os séculos VII e VIII a.C, pelo rei assírio Assurbanipal II, na cidade de mesmo nome da Biblioteca. Segundo Báez (2006, p. 38) "seu reinado foi difícil, mas ele, primeiro rei a obter instrução necessária para escrever tabletas", "provavelmente foi o primeiro governante a combinar a espada à escrita e a leitura”. Esta biblioteca, considerada como a mais antiga na história das bibliotecas, descoberta por meio de escavações arqueológicas, no final do século XIX, era composta por inúmeras tabuinhas, cerca de vinte e cinco mil, dispostas de maneira organizadas nas prateleiras, e continham a descrição do autor e conteúdo nas etiquetas, que ficavam presas ao suporte ou nas embalagens protetoras. Para Pereira e Santos (2014, p. 16) essa breve descrição das obras pode ser vista como "embrião dos catálogos". Além de ser considerada a primeira biblioteca, deriva de seu acervo a primeira obra literária, a "Epopeia de Gilgamesh" que "prenuncia as grandes lendas da mitologia grega, particularmente, 'Os trabalhos de Hércules' contém, também, uma extraordinária evocação do dilúvio, prefigurando a da Bíblia” (JEAN, 2008, p. 20).

Fischer (2006, p. 26) relata que essa "biblioteca continha uma porcentagem elevada, fora do comum, de escritos cerimoniais, além de astrologia, presságios e palavras de feitiçaria - ou seja, recursos para compreender, apaziguar e coagir dos deuses". Esse acervo de tabuinhas de barro cozido e em escrita cuneiforme constitui os primórdios das primeiras manifestações de atividades dentro de uma biblioteca, como as ações de catalogação,

V.16

n.3

p. $254-273$

set./dez. 2018 
armazenamento e recuperação. A biblioteca do Palácio de Ebla, na Síria, abrigava cerca de dezessete mil tabuinhas que abordavam uma diversidade de assuntos: história, literatura, agricultura, idiomas, mas acima de tudo, finanças e economia, ou melhor, apenas uma pequena porcentagem não tratava de assuntos administrativos (FISCHER, 2006). Essa quantidade de tabuinhas de argila aproxima-se da Biblioteca de Nippur, que continha cerca de quinze mil tabuinhas armazenadas na cidade suméria de mesmo nome.

Para Pettinato (1994) o primeiro princípio da Biblioteconomia deriva dessas primeiras atividades de organização temáticas das tabuinhas, portanto, para este autor pode-se dizer que a biblioteconomia não começou com a Biblioteca de Alexandria ou a Biblioteca de Pérgamo (localizada na cidade de mesmo nome, e que buscava rivalizar com a Biblioteca de Alexandria), as quais são mais citadas e conhecidas, mas com as tabuinhas de argila da Biblioteca de Ebla. Essas tábuas, segundo Martins (2002), constituíram o principal suporte das bibliotecas antigas da Mesopotâmia, conhecidas também como "bibliotecas minerais", em decorrência do material dos suportes, tanto o barro, argila, como as pedras, as quais foram sucedidas pelas "bibliotecas vegetais", de papiros, e as "bibliotecas animais", de pergaminhos.

Na Grécia as bibliotecas eram menos numerosas quando comparadas com outros países. Para Martins (2002), esse fato decorre da forte cultura oral, dos teatros e templos de discussão, em detrimento da escrita. Era comum a leitura pública e os círculos de leitura, no período diurno, para aproveitar a luz solar, "em geral, no átrio aberto ou pátio. Poucos, no entanto, tinham esse tempo livre à disposição durante o dia" (FISCHER, 2006, p. 67). Segundo Martins (2002) em Roma as bibliotecas dividiam-se entre particulares e públicas, as primeiras compostas, sobretudo, por livros saqueados de guerras e de materiais produzidos pelos escribas ou escravos. As bibliotecas particulares eram vinculadas aos mais abastados, como Cícero, considerado uns dos maiores filósofos da Antiguidade. Dentre as bibliotecas particulares, com cerca de 1.800 rolos e com inúmeras obras gregas, destaca-se a biblioteca do sogro de Júlio César, Lúcio Calpurnio Pisone. Homens estudiosos, como Teofrasto e Eurípedes, também possuíam em suas residências bibliotecas particulares.

Já o modelo de biblioteca pública idealizada por Júlio César e concretizado pelos seus partidários Asínio Pólio e Públio Terêncio Varrão veio à luz em 39 a.C, no Fórum Romano. A biblioteca pública de Roma era composta por duas salas, uma de livros em latim e outra de livros em grego, ambas decoradas com estátuas de poetas e oradores dos dois idiomas. Após essa biblioteca, outras bibliotecas foram criadas pelos imperadores, com a Biblioteca Palatina, por Augusto, e a Biblioteca Ulpiana, por Trajano, constituindo as duas mais importantes bibliotecas dentre as vinte e oito bibliotecas públicas de Roma (MARTINS, 2002).

Ao longo desse período a figura do "bibliotecário" estava relacionada com a imagem do homem letrado e sábio que desempenhava atividades vinculadas ao funcionamento e

n.3

p. $254-273$
set./dez. 2018 
organização das bibliotecas. Segundo Chaui (2010) o primeiro bibliotecário da Biblioteca de Alexandria foi Zenódoto, responsável pela edição das obras de Homero, que dividiu a Ilíada e a Odisséia em vinte e quatro volumes. Seu sucessor, Calímaco de Cirene, organizou e preparou as tábuas dos autores que tinha a função de servir como um guia bibliográfico apto a orientar as pesquisas dos hóspedes do museu (JACOB, 2000). Essa atividade deu origem ao primeiro catálogo das obras da biblioteca de Alexandria, nomeado de pinakes, composto por cento e vinte volumes, que relatava os autores em ordem alfabética, acompanhados de uma pequena biografia, bibliografia e de comentários sobre critérios para a distinção entre obras autênticas e apócrifas. Pereira e Santos (2014) relatam também que os volumes traziam nos syllabus, ou seja, nas etiquetas, informações sobre o número de linhas de cada obra, suas palavras iniciais e os dados sobre autores, as quais podem ser consideradas como antecedentes das fichas de identificação.

Sobre a organização da coleção da Biblioteca de Alexandria sabe-se que ela chegou a ser dividida por Calímaco de Cirene em oito seções temáticas: drama, oratória, poesia lírica, legislação, medicina, história, filosofia, e "diversos" (FISCHER, 2006). Embora, Estrugas Mora (2005) aborde que Calímaco não chegou a assumir a direção da biblioteca de Alexandria, ele aponta os seguintes homens ilustres, que assumiram o papel de bibliotecário em Alexandria: Apolonio de Rodas, Eratóstene de Cirene, Aristófanes de Bizânzio, Apolonio de Alexandria, Eidógrafo e Aristarco da Samotrácia, nomes que formaram a primeira geração de notáveis na direção da biblioteca de Alexandria. Segundo Báez (2006, p.65) eram homens que assumiam a direção da biblioteca mediante desígnio do rei. O diretor "vivia no palácio do rei e recebia toda a espécie de incentivos econômicos para evitar possível suborno ou traição. Não pagava imposto. Exercia, sem poder de eximir, a tutela do filho do rei”.

Por fim, Fischer (2006) aponta que nos últimos séculos antes de Cristo, os rolos de papiros vão se tornando cada vez mais escassos, e com isso, o pergaminho vai ganhando maior prestígio, e por volta do século IV d.C, já o havia substituindo quase por completo. O pergaminho se destaca em decorrência de sua materialidade, mais durável e resistente, e também por proporcionar uma maior economia de espaço nas bibliotecas, tendo em vista a constituição dos códices com seus cadernos (folhas encadernadas). Ademais, podia ser lido com uma das mãos, possibilitava a consulta a trechos das obras, sem precisar desenrolar o suporte, como era o papiro. O pergaminho abriu espaço para outro tipo de leitura, uma leitura silenciosa e introspectiva, voltada para a busca pessoal, bem aos moldes do cristianismo, o que assegurou o triunfo do códice de pergaminho ao longo de todo o período medieval (MARTINS, 2002; FISCHER, 2006).

\section{AS BIBLIOTECAS NA IDADE MÉDIA}

As bibliotecas compostas por inúmeros pergaminhos expandiram-se durante os séculos V a XV d.C, período este conhecido como Idade Média. Esse suporte, feito de pele de animal, era mais resistente que os anteriores (tabuinhas e papiros), o que possibilitava a

n. 3

p. $254-273$

set./dez. 2018


escrita nos dois lados e a costura no dorso das páginas, dando forma ao códex, precursor imediato do livro. Embora, a materialidade dos suportes tenha melhorado nesse período medieval, as bibliotecas continuaram fechadas em si mesmas, pois apenas uma parcela reduzida da população tinha acesso a elas, reduzindo-as "depósitos", um local onde mais se esconde do que se revela, assim como um local de silêncio. Em um primeiro momento, as bibliotecas vincularam-se, sobretudo, a um espaço sagrado, como os mosteiros e os conventos, e num segundo momento, a lugares de estudo, como as universidades, devendo em ambos os momentos os poucos leitores à época zelarem pelo silêncio nas bibliotecas.

Segundo Fischer (2006) a Europa ocidental iniciou a transição de uma sociedade oral para uma sociedade letrada no início da Idade Média, começando com as camadas mais altas, como a aristocracia e o clero. Deste modo, a leitura individual passou a ter o mesmo valor e legitimidade da oralidade, muito embora ainda fossem realizadas leituras em voz alta, uma experiência coletiva dentro dos mosteiros, igrejas, conventos, universidades e residências. Essa leitura envolvia a decifração do latim, a língua "veículo da cristandade e de toda educação" (FISCHER, 2006, p. 137), cujo alcance era internacional e possuía caráter oficial. Tanto que, "apenas quem soubesse ler em latim era um literattus: uma pessoa capaz de ter acesso ao conhecimento escrito, bem como de compartilhá-lo" (FISCHER, 2006, p. 137). Já no final da Idade Média, com o aumento da alfabetização, a mediação da igreja católica e de religiosos se tornou cada vez menor, os próprios letrados poderiam estabelecer essa comunicação com o divino por meio da letra, do livro, que com o tempo também deixou de ter esse efeito milagroso para a população medieval, pois já não era apenas da leitura do padre que se tinha acesso às palavras de Deus (FISCHER, 2006).

Essa figura da biblioteca como um espaço fechado, de depósito, possibilitou, ainda, de modo indireto, pois não era essa a intenção, a preservação dos registros e da cultura grecoromana, depois valorizada com o Renascimento (movimento cultural, artístico e intelectual), que significou uma profunda ruptura com este momento, inaugurando posteriormente a Idade Moderna. Contudo, antes dessa ruptura com o modelo anterior, Martins (2002) salienta que a arquitetura das bibliotecas na Antiguidade e na Idade Média revelava essa concepção fechada das mesmas, como no caso das portas que davam geralmente para o interior de onde estavam localizadas. Esse autor afirma ainda que, predominava o espírito de armazenamento e preservação das obras, de modo que "as bibliotecas medievais, são, na realidade, simples prolongamentos das bibliotecas antigas, tanto na composição, quanto na organização, na natureza e no funcionamento", as mudanças sofridas são insignificantes, decorrentes apenas de pequenas divergências de ordem social (MARTINS, 2002, p. 71). Assim, acrescenta-se que, "as sandálias macias do monge medieval repetiam, no eco das abóbadas, o mesmo som ancestral dos sacerdotes sumerianos da biblioteca de Assurbanipal" (MARTINS, 2002, p. $71)$.

Sobre essa disposição das bibliotecas, Belo (2002) diz ainda que os livros ficavam armazenados em armários ou armarium fechados à chave ou mesmo presos a correntes. Os

n.3

p. $254-273$

set./dez. 2018 
livros eram, sobretudo, objetos preciosos, "o valor de um livro era, para um homem de saber, simultaneamente simbólico e material", por isso eram conservados dentro dos armários e cofres (VERGER, 1999, p. 117). Como discorre Verger (1999) os livros durante esse primeiro momento da Idade Média custavam muito caro devido ao suporte, o pergaminho que era utilizado em grandes quantidades para a confecção do livro. $O$ custo da cópia decorria também do valor dos bons copistas que eram mais caros e viviam nas cidades (capitais da nobreza e cidades universitárias). Em um segundo momento, de crescimento das cidades e das universidades, os livros passaram a ser vistos como uma necessidade ligada aos ensinamentos não apenas religioso, mas científicos. Torna-se assim premente o barateamento dos livros, os quais adquirem formatos menores, a escrita mais simples e cursiva, mais apertada na página e escrita com pena de ave, multiplicação de abreviaturas, rubricas, índices e diminuição de iluminuras e miniaturas (VERGER, 1999; REIMÃO, 2004).

Sobre as bibliotecas da Antiguidade e as bibliotecas da Idade Média, Fischer (2006, p. 183) apresenta que as bibliotecas do medievo eram menores em quantidade de itens em seus acervos do que as bibliotecas anteriores; "As primeiras bibliotecas reais e monásticas da Europa nunca chegaram a possuir mais do que algumas centenas de livros em acervo, tornando a catalogação desnecessária". Desse modo, algumas bibliotecas tinham fichas precárias referentes às estantes ou mesmo listas com as primeiras palavras dos textos, quando os títulos não eram oficiais, sendo raros os casos de autores listados em ordem alfabética. Os catálogos constituíam, assim, quando eram feitos uma espécie de lista bibliográfica, um inventário descritivo, o que refletia em uma técnica pouco elaborada (PEREIRA; SANTOS, 2014). Em relação à catalogação por assunto, que era bastante incomum, tem-se relato desse uso no século XI, na catedral de Le Puy em Haute-Louire, na França. Sobre a guarda dos livros, Fischer (2006, p. 183) declara ainda que "os livros, em geral, eram organizados nas prateleiras de acordo com o uso, sendo sua posição apenas memorizada por um atendente mais experiente, a quem todos recorriam na hora de encontrar um texto desejado".

Martins (2002) apresenta três espécies de bibliotecas durante esse período da Idade Média: bibliotecas monásticas, bibliotecas universitárias e bibliotecas particulares. Sobre o conteúdo dos livros, das bibliotecas monásticas, Alonso (2006) aborda três núcleos: o fundo mais numeroso que constituíam os livros litúrgicos; no segundo fundo havia os livros de conteúdo espiritual para a lectio divina (hagiografia e obras dos padres da igreja); e, por último, o terceiro grupo, que era composto pelas miscelâneas, os libri artium, obras de autores pagãos, latinos, assim como gramáticas para o aprendizado de latim. Já nas bibliotecas particulares os livros seguiam os gostos e necessidades de seus proprietários, enquanto que nas bibliotecas institucionais, ou universitárias, os conteúdos dos livros se apoiavam nas disciplinas, os acervos eram um reflexo do currículo, do ensino, e eram ordenados segundo as matérias do triuvium (Gramática, Retórica e Lógica) e do quadrivium (Aritmética, Geometria, Astronomia e Música). Dentro desse grupo, os livros eram normalmente organizados por tamanho: in-fólio na parte inferior da estante, os formatos inquarto na parte central e os in-oitavo na parte superior. A razão para esse armazenamento era

\begin{tabular}{|c|c|c|c|c|c|}
\hline (C) RDBCI: Rev. Digit. Bibliotecon. Cienc. Inf. & Campinas, SP & v.16 & n. 3 & p. 254-273 & set./dez. 2018 \\
\hline
\end{tabular}


pragmática, no sentido de que os livros que pesavam mais ficavam em baixo, os livros com peso mediano no meio, e os livros mais leves em cima (ALONSO, 2006).

Não diferente das bibliotecas anteriores, da Antiguidade, as bibliotecas do período medieval são marcadas pelas presenças dos copistas - homens destinados à cópia de textos. Essas cópias eram realizadas nos scriptorium, localizados nos mosteiros e conventos das ordens religiosas dos franciscanos, dominicanos e beneditinos, e depois no próprio espaço das bibliotecas nas universidades. Nas oficinas a mando dos superiores, os monges copiavam, sobretudo, as obras sagradas, mas os beneditinos copiavam tanto esses textos como textos profanos produzidos no período histórico anterior (MARTINS, 2002). Salienta-se que os monges, nesse período, são associados às bibliotecas, de modo que cada mosteiro tinha uma biblioteca, sendo os monges representados em meio aos livros, seja devido a atividades de cópia ou de leitura, que servia para combater o ócio, inimigo da alma. Na Alta Idade Média, aponta-se a importância da Biblioteca de Cassiodoro (século VI), da Biblioteca de São Bento (Século VII) e do tempo de Alcuíno (século X), que se ocuparam da produção de livros, de cópias de obras, bem como da preservação e armazenamento dos livros da época anterior e de sua época (BATTLES, 2003).

Quanto à atividade de ilustração das obras, esse exercício assumiu um espaço maior nas oficinas, do que na Antiguidade, tendo sido criadas no medievo as categorias das iluminuras e das miniaturas. Ademais, ao lado das orações e das leituras, o trabalho manual dos monges copistas era representado por todo o processo de confecção da obra, desde o preparo do pergaminho, cópia dos livros, confecção das iluminuras, do colofão até a encadernação. Segundo Martins (2002) as cópias dos livros assumiam uma espécie de rito espiritual, capaz de aprimorar as virtudes e de realçar os merecimentos desses homens. A Bíblia foi a principal obra copiada durante toda a Idade Média, assim como foram feitos inúmeros "livros de horas", textos religiosos que continham orações para cada hora dia, nos quais eram, geralmente, ilustrados e ornamentados com pedras preciosas, marcando as encadernações de ourivesaria.

Martins (2002) destaca que, entre as mais célebres bibliotecas conventuais da Idade Média estão as bibliotecas italianas, francesas, suíças e prussianas, assim como a do Montes Atos, na Turquia, e a biblioteca Vaticana, relacionada com o papa Hilário, estabelecida na Basílica de São João de Latrão. No século IX começam as surgir as bibliotecas capitulares, ligadas à igreja, e dentre elas as mais famosas são as das: Catedrais de Chartes, Lyon, Reims, Cambrai, Rouen, Clermont (MARTINS, 2002). Não distante da noção da biblioteca como um espaço privilegiado, existiram nesse período diversas bibliotecas particulares, sobretudo, de reis e imperados, como Carlos Magno iv, detentor de uma biblioteca com inúmeros livros ilustrados, e, Carlos V, da França, que chegou a reunir mil e duzentos volumes, um número considerável no seu tempo, que viria a constituir o acervo da Biblioteca Nacional de Paris. 
Tais bibliotecas depois desse momento obscuro passaram a ser consideradas "oficiais", isto é, sob o controle do estado, abertas ao público com horários flexíveis e acervos mais democráticos. Essa mudança operou em decorrência do aperfeiçoamento da imprensa, que mudou a história das bibliotecas, inicialmente marcada por alguns poucos homens possuidores de riquezas, poderosos e desejosos de reunir e produzir o conhecimento do mundo, como na Antiguidade e na Idade Média. Nesses dois momentos, o antigo e o de transição, o livro era visto como objeto disponível apenas para os privilegiados, não fazendo parte da vida cotidiana do restante da população. Além disso, sabe-se que era total o analfabetismo das classes populares durante a Idade Média, sendo, então, nulo a circulação e o uso o livro, da leitura e da biblioteca. Logo, os livros não eram destinados a essa classe, os livros não faziam parte do cotidiano das pessoas (MARTINS, 2002).

Contudo, ainda no medievo ocorre uma virada na história das bibliotecas, em razão do nascimento das bibliotecas universitárias, as quais estão vinculadas a criação das universidades medievais , a partir do século XII. Dessa forma, os livros passaram a ser vistos e sentidos como instrumentos de trabalho, um objeto de apoio à atividade de ensino de alunos e professores, o que permitiu também o início do processo de laicização dos livros por meio das cópias de outros livros que não os religiosos realizados por copistas leigos (MARTINS, 2002). Os livros progressivamente distanciam-se do universo religioso, de objeto sagrado, e aproximam-se do universo de estudo, de objeto de pesquisa, demandando inclusive um aprimoramento dos catálogos para que os livros pudessem ser localizados, um claro deslocamento da maneira de pensar sobre o livro (SILVEIRA, 2014).

Durante o período da Idade Média, os livros assumiram duas significações, uma do livro como objeto sagrado (predominante na Alta Idade Média) e a outra como o livro como instrumento de trabalho (na Baixa Idade Média), podendo os alunos das universidades de Bolonha, Sorbonne, Oxford, Cambride e Toulosse, solicitar cópias de algumas obras mediante o pagamento de uma taxa. Embora, a figura do livro tivesse modificado ou ampliado suas funções, as bibliotecas das universidades medievais continuavam ainda como espaços fechados, abertos apenas para os autorizados, e compostas por livros amarrados as estantes a fim de manter a ordem, o controle do que era lido, bem como dificultar o extravio de livros. Não obstante, o "bibliotecário" continuava associado à figura do livro, imerso em uma relação de custódia da coleção, daquele homem que "contava os livros, ia buscá-los, para depois devolvê-los às estantes” (BATTES, 2003, p. 123).

Embora esse momento da história seja visto a partir de certo obscurantismo, é em razão da fuga dos monges e sábios bizantinos para o Ocidente, por conta da tomada de Constantinopla, em 1453, que a Renascença encontra a possibilidade de florescimento com os manuscritos e os conhecimentos acumulados durante a Idade Média. Sobre isso, Martins (2002, p. 96) salienta que "a Renascença não teria sido possível, no que concerne às obras escritas, se a Idade Média não tivesse possuído esses enormes silos que foram as suas bibliotecas monásticas, universitárias e particulares". Movimento este laico, que rompe com o

\begin{tabular}{|c|c|c|c|c|c|}
\hline (C) RDBCI: Rev. Digit. Bibliotecon. Cienc. Inf. & Campinas, SP & v.16 & n. 3 & p. $254-273$ & set./dez. 2018 \\
\hline
\end{tabular}


sistema de conhecimento anterior enclausurado nas ordens religiosas, colocando a disposição os saberes e valorizando os conhecimentos produzidos, sobretudo, pelos antigos. Posteriormente, em 1462, com a tomada de Mogúncia, pela tropa de Nassau, a imprensa vulgariza-se, devido à dispersão dos tipógrafos pela Europa (MARTINS, 2002), o que contribui ainda mais para a alteração da relação do livro, da biblioteca e do bibliotecário frente à sociedade.

\section{BIBLIOTECONOMIA PRÉ-CIENTífica}

A palavra Biblioteconomia segundo sua etimologia pode ser decomposta em três elementos: Biblion $=$ livro, Theke $=$ armazém e nomo $=$ administração ou descrição, resultando assim na concepção de Biblioteconomia como organização e administração de bibliotecas (biblioteca + economia). Outro termo similar a este é o de Bibliotecología, o qual consiste na união de Biblio = livro, Theke = armazén e Logos = estudo, sendo, portanto, mais amplo que o anterior devido ao sufixo logos, que significa ciência, ou seja, a ciência das bibliotecas. Esses termos, de origem latina e grega, serão trabalhados como conceitos científicos séculos depois da Antiguidade, momento este em que prevaleceram os primeiros saberes empíricos da área. Assim, a prática da Biblioteconomia ou Bibliotecología já era exercida nos espaços das primeiras bibliotecas, daí o esforço histórico de retornar as mais tenras bibliotecas e produções precursoras do campo.

Outra coisa que se busca relatar é de que, embora as bibliotecas naquele momento antigo não tenham sido norteadas por conhecimentos teóricos de um campo específico, a Biblioteconomia, houve, por outro lado, alguns esforços em torno dessa matéria. $\mathrm{Na}$ Antiguidade, o primeiro catálogo produzido por Calímaco de Cirene, inaugurou as bases para a organização dos registros do conhecimento, utilizando como descritores os títulos das obras, os autores, contando inclusive com uma breve biografia e a divisão por assunto. Galeno de Pérgamo escreveu De libris propilis liber e Ordine librorium liber, os quais podem ser considerados antecessores dos repertórios bibliográficos. No livro VI da obra De Architectura, o capítulo IV, abordava orientações sobre a construção dos espaços, entre eles a biblioteca e a pinacoteca romana. A Biblioteca de Celso, construída em homenagem ao Tibério Júlio Celso Polemeno, em 135 d.C, seguiu esse manual romano sobre a arquitetura do espaço, em que a única sala do edifício estava a leste, devido à incidência dos raios de sol da manhã, porque seus usos requerem a luz do dia.

Ainda na Antiguidade foi escrito por Marco Terencio Varrón o livro De bibliothecis III cuja temática era a organização de bibliotecas. Segundo Valcárcel (2004) coube a Varrón a compra dos livros e a classificação em duas salas, uma grega, outra latina, com base no critério linguístico-geográfico da Biblioteca Pública de Roma. O imperador romano Tiberio criou o cargo administrativo, denominado procurator bíbliothecarum, vinculando a biblioteca a este profissional (PULIDO; MORRILAS, 2010). Além dessa iniciativa de profissionalização do bibliotecário, Valcárcel (2004) aponta que havia também o cargo

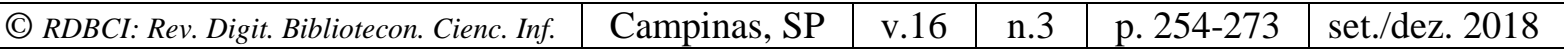


bibliothecarius ou magister a bibliotheca destinado a atividades como conservar a coleção, efetuar cópias, ordenar os rolos em seus armários ou estantes, confeccionar o titulus e talvez relatar um catálogo ou lista de obras publicadas.

Durante a Idade Média houve, ainda que "tímido", um esforço de sistematização do funcionamento das bibliotecas, considerada um espaço de conservação das obras, centrada na organização, tendo a figura dos catálogos como forma de inventário. Pereira e Santos (2014) citam o catálogo do mosteiro beneditino de Saint Requier, na França, o qual era composto de 246 volumes, bem como o catálogo do mosteiro de Bobbio, na Itália, no qual registrava 700 volumes e o do mosteiro de Lorsch, na Alemanha, com 600 volumes. Produções consideradas específicas e essenciais do fazer biblioteconômico. Magno Aurelio Cassiodoro, fundador do mosteiro de Vivarium, em 550 d.C, escreveu a obra Institutiones divinarum et secularum litterarum, que se constitui em um tratado das regras de funcionamento de uma biblioteca e de um scriptorium, bem como aborda a seleção de obras que uma biblioteca monástica dedicada ao estudo deveria possuir em seu acervo. Uma clara preocupação com que se chama hoje de "Formação e desenvolvimento dos acervos".

Isidoro de Sevilla autor da obra Etimologías (publicada em torno de 630) composta pelos capítulos De libris et officiis ecclesiaticis, De medicina et bibliothecis e De librariis et eorum instrumentis traz nos dois primeiros capítulos o desenvolvimento de coleções para eclesiásticos e médicos e no terceiro capítulo os instrumentos de trabalho como a elaboração de códices, conhecimento do documento e o trabalho do monge. Em virtude da extensão, 448 capítulos em 20 volumes, essa obra pode ser considerada como uma das primeiras enciclopédias do medievo. Nesse momento, a fim de reunir o conhecimento disponível cita-se esforços de Bartholomeus Anglicus, que escreveu De Rerum proprietatibus (1240) e Vicente de Beauvais, com Speculum Majus (1260).

Ainda em 1260, foi escrito o tratado de Biblioteconomia, de autoria de Domenicano Humberto de Romanis, autor da obra Instructio officialium, composta pelo capítulo denominado Librarius (VALENZUELA, 1998; PULIDO; MORRILAS, 2004). Richard de Fournival, autor da obra Biblionomía, escrita no século XIII, consiste num conjunto de regras para a organização de coleções (PULIDO; MORRILAS, 2004). Não obstante, o primeiro registro de um catálogo entre bibliotecas, remonta ao medievo, especificamente a 1250-1296 com a obra Registrum librorum angliae, que reunia as informações sobre o acervo dos 183 mosteiros franciscanos ingleses (SERRAI, 1975). Nessa mesma linha, foi escrito durante a baixa Idade Média, Informatorium bibliothecarii, de Georgius Carpentarius, e publicado em 1888, por Ludwig Sieber.

Nesse momento, de criação das primeiras bibliotecas das universidades europeias, Richard de Bury estabeleceu em seu livro Philobiblon ou "amigo do livro", regras de acesso à biblioteca de Oxford, como por exemplo: o empréstimo estava condicionado a uma espécie de promissória que era superior ao valor do livro, sendo, apenas, os selecionados que podiam

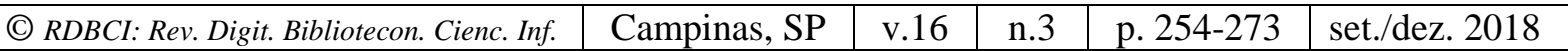


realizar o empréstimo, mediante anotação do título e a data do empréstimo, não podendo sair da cidade ou seus subúrbios com o livro. Quanto aos livros com duplicatas perdidas os mesmos não poderiam sair da sala da biblioteca (BURY, 2007). Ademais, o livro de Bury salienta o amor aos livros, os quais são vistos como mestres dos mestres, tesouro infinito dos homens e riqueza maior que todas as riquezas, inclusive a "biblioteca de sabedoria é mais preciosa do que todas as riquezas, e todas as cousas desejáveis não se podem comparar a ela" (BURY, 2007, p. 34). Assim, esta obra parte sobre um regulamento de uma biblioteca, parte sobre a "bibliofilia", escrita em 1345, "trata-se do que pode ser considerada a primeira publicação - desde que os sumérios escreveram cuneiformes nas ancestrais tabuinhas de argila - a abordar exclusivamente a paixão pelos livros" (ROLLEMBERG, 2004, p. 9).

\section{CONSIDERAÇÕES FINAIS}

É possível perceber que a figura do bibliotecário está intimamente relacionada com o espaço das bibliotecas entre as tabuinhas, os rolos de papiro e os códices de pergaminho. $\mathrm{O}$ bibliotecário de ambos os momentos retratados, Antiguidade e Idade Média, era um cargo destinado a homens de douto saber, homens selecionados para atividades de organização dos acervos, descrição e criação de instrumentos de recuperação e controle. As palavras de ordem que ilustram estes momentos são: posse, guarda, controle, armazenamento, vigilância e preservação dos acervos. As bibliotecas e os bibliotecários representavam assim uma espécie de distinção social, a começar pelo espaço físico (destinado a poucos privilegiados) e das coleções associadas à cultura da palavra escrita e erudita, passando pelo homem privilegiado por saber ler e escrever. Essa imagem da biblioteca como espaço de distinção, de demonstração de uma soberania política, econômica, cultural e intelectual de um grupo de pessoas, permanecerá na Antiguidade dos reis e letrados, e na Idade Média, por meio das ordens religiosas e dos universitários.

Em relação às produções do conhecimento, estas aumentaram gradativamente ao longo dos séculos, na Idade Média foram mais substanciais as produções em torno da biblioteca e de seus fazeres quando comparado com as produções da Antiguidade no que se refere a um conhecimento biblioteconômico. Mesmo que a Biblioteconomia seja ainda vista como arte ou ofício, durante estes dois momentos, tais ações foram de suma importância para a formação dos conhecimentos e sua posterior consolidação como campo científico. Percebese, então, que nesse primeiro momento denominado de Biblioteconomia pré-científica ou de Biblioteconomia tradicional, as produções voltavam-se para o fazer, para o cotidiano e suas necessidades internas: como selecionar e descrever as coleções, como organizar e administrar as bibliotecas. Em síntese, a Biblioteconomia inicia sua trajetória em decorrência das práticas exercidas ainda nas primeiras bibliotecas, as quais são imbuídas do espírito conservacionista, pelo menos até o século XV, que se denomina de Biblioteconomia pré-científica (PULIDO; MORRILAS, 2010). 


\section{REFERÊNCIAS}

BÁEZ, Fernando. História universal da destruição dos livros: das tábuas sumérias à guerra do Iraque. Rio de Janeiro: Ediouro, 2006.

BASTOS, Gustavo Grandini. Bibliotecas: uma reflexão história acerca da constituição dessas instituições. Disponível em: http://www.letras.ufscar.br/. Acesso em: 12 mar. 2015.

BATTLES, Matthew. A conturbada história das bibliotecas. São Paulo: Planeta do Brasil, 2003.

BELO, André. História \& livro e leitura. 2. ed. Belo Horizonte: Autêntica, 2002.

BURY, Ricado de. Philoobilon ou o amigo do livro. São Paulo: Atelie Editorial, 2007. Traduzido por Macelo Cid.

BURKE, Peter. Problemas causados por Gutenberg: a explosão da informação nos primórdios da Europa moderna. Estudos avançados, v. 44, n. 12, 2002.

CANFORA, Luciano. A biblioteca desaparecida: histórias da biblioteca de Alexandria. São Paulo: Cia. das Letras, 1989.

CHAUI, Marilena. O museu e a biblioteca: as ciências na época helenística. In:

Introdução à história da filosofia: as escolas helenísticas. São Paulo: Companhia das Letras, 2010. v.2.

EISENSTEIN, Elizabeth. A Revolução da cultura impressa. São Paulo: Ática, 1998.

FISCHER, Roger Steven. História da Leitura. São Paulo: Unesp, 2006.

FLOWER, Derek Adie. Biblioteca de Alexandria: as histórias da maior biblioteca da antigüidade. São Paulo: Nova Alexandria, 2002.

JACOB, Christian. O poder das bibliotecas: a memória dos livros no Ocidente. Rio de Janeiro: Ed. da UFRJ, 2002.

JEAN, Georges. A escrita: memória dos homens. Rio de Janeiro: Objetiva, 2008.

GOULEMOT, Jean Marie. O amor às bibliotecas. São Paulo: UNESP, 2011.

LINARES COLUMBIÉ, Radames. La Bibiotecología y sus orígenes. Ciencias de la información, v.35, n.3, diciembre, 2004.

MANGUEL, Alberto. A biblioteca à noite. São Paulo: Companhia das Letras, 2006.

MARTINS, Wilson. A palavra escrita: história do livro, da imprensa e da biblioteca. São Paulo: Ática, 2002. 
ORTEGA, Cristina. Relações históricas entre Biblioteconomia, Documentação e Ciência da Informação. DataGramaZero - Revista de Ciência da Informação - v.5 n.5 out. 2004.

PEREIRA, Ana Maria; SANTOS, Plácida Leopoldina. Catalogação: breve histórico e contemporaneidade. Rio de Janeiro: Intertexto, 2014.

PETTINATO, Guiovanni. En los Orígenes de la Biblioteconomia y Documentación: Ebla. Documentación de las ciencias de la información, Madrid, n. 17, 1994.

PULIDO, Margarita Pérez; MORILLAS, José Luis Herrera. Teoria e nuevos escenarios de la Bibliotecología. Buenos Aires: Alfagrama, 2010.

REIMÃO, Sandra. Observações sobre a história do livro. 2004. Disponível em: http://escritoriodolivro.com.br/historias/sandra.html. Acesso em: 12 nov. 2014.

SERRAI, Alfredo. História da biblioteca como evolução de uma idéia e de um sistema. $R$. Escola de Biblioteconomia, UFMG, Belo Horizonte, v.4, n.2, p.141-161, 1975.

SILVA, Armando B. Malheiro da; RIBEIRO, Fernanda. Arquivística: teoria e prática de uma ciência da informação. Porto: Afrontamento, 1999.

SILVEIRA, Fabrício José Nascimento da. Biblioteca pública, identidade e enraizamento: elaborações intersubjetivas ancoradas em torno da Luiz de Bessa. 2014. 253f. Tese (doutorado) - Universidade Federal de Minas Gerais, Escola de Ciência da Informação.

TANUS, Gabrielle Francinne. Da prática à produção do conhecimento: bibliotecas na modernidade e biblioteconomia protocientífica. RDBCI: Revista Digital de Biblioteconomia e Ciência da Informação, Campinas, SP, v. 13, n. 3, p. 546-560, set. 2015.

TANUS, Gabrielle Francinne. A constituição da biblioteconomia científica: um olhar histórico. RDBCI: Revista Digital de Biblioteconomia e Ciência da Informação, Campinas, SP, v. 14, n. 2, p. 217-231, maio 2016.

VALCÁRCEL, José A. Rodríguez. Procurator Bibliothecae Augusti: los Bibliotecarios del emperador en los inicios de las Bibliotecas Públicas en Roma.Anales de Documentacion, n. 7, 2004.

VALENZUELA, Hortensia García. Una aportación teórica a la evolución del concepto, término y definición de Biblioteconomía. Revista General de Información y Documentación, v. 8, n.1, 1998.

VERGER, Jacques. Homens e saber na Idade Média. Bauru, SP: EDUSC, 1999.

\footnotetext{
' Planta da família Cyperus papyrus, suporte amplamente utilizado na Antiguidade, suas fibras são longas e finas, as quais eram sobrepostas umas as outras, depois pressionadas, formando uma folha delgada para a escrita. Os papiros eram enrolados em uma haste de madeira ou marfim, chamada umbilicus, dando forma aos
}

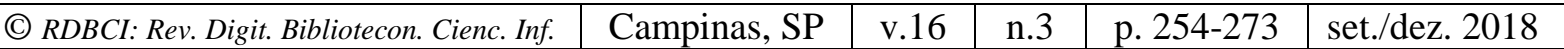


rolos ou volumen. Além da fabricação da "folha" para o registro, Jean (2008) acrescenta que, o papiro era empregado para fabricar diversos objetos do dia-a-dia, tais como corda, esteiras, sandálias e velas de barco.

ii A Biblioteca de Pérgamo, localizada na cidade de Pérgamo no Egito, era depois da Biblioteca de Alexandria a segunda mais importante biblioteca. Seu acervo era constituído de aproximadamente duzentos mil volumes. Foi criada por Átalo I e fortificada por Eumênio II, que ordenou também que fosse criado outro suporte após a proibição da exportação do papiro por Ptolomeu V. Assim foi criado o pergaminho, esse suporte era feito com a pele de animal (cabra, carneiro, ovelha) ou mesmo da pele do animal natimorto ou recém-nascido, suporte conhecido como velino, que é de melhor qualidade por ser mais fino e mais liso, destinado a manuscritos de luxo, e que, perdurará até o final da Idade Média, sendo o principal suporte desse período, cujo formato, o códice, consistirá no precursor imediato do livro (MARTINS, 2002).

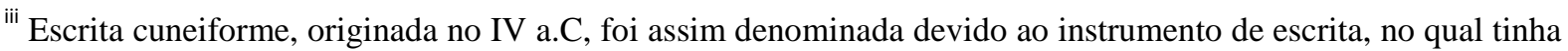
em sua extremidade uma haste que possibilitava o entalhe dos caracteres no barro, na argila, no formato de cunha. Segundo Fischer (2006) a escrita cuneiforme poderia ser também encontrada em pedra e gravadas em cera, marfim, metal e, até mesmo, vidro.

${ }^{\text {iv }}$ Criou a Escola Palatina, durante o seu reinado, que ficou conhecido como Renascimento Carolíngio, essa escola, composta por uma biblioteca considerada como a maior da Europa nesse tempo, serviu como modelo para outras escolas, a organização do ensino dividia-se nas sete artes liberais: Trivium (trabalhava com o uso da mente) e Quadrivium (trabalhava a matéria, com princípios lógicos e rápidos). Segundo Burke (2002) os livros das bibliotecas das universidades seguiam essa organização, de modo que, a organização curricular ditava a organização das bibliotecas.

"Segundo Battles (2003) as universidades europeias foram inspiradas nas "casas de sabedoria" do mundo mulçumano criadas no século IX, em um momento de prosperidade científica, cultural e religiosa. Essas casas de sabedoria estabelecidas por Califa Abássida eram constituídas por uma biblioteca, escola e centro de pesquisa e de tradução, sendo considerada uma instituição central no movimento das traduções e intelectual durante a idade de ouro no Islã. E, capaz de satisfazer a todas as necessidades de um jovem intelectual bem dotado (BATTES, 2003, p. 66).

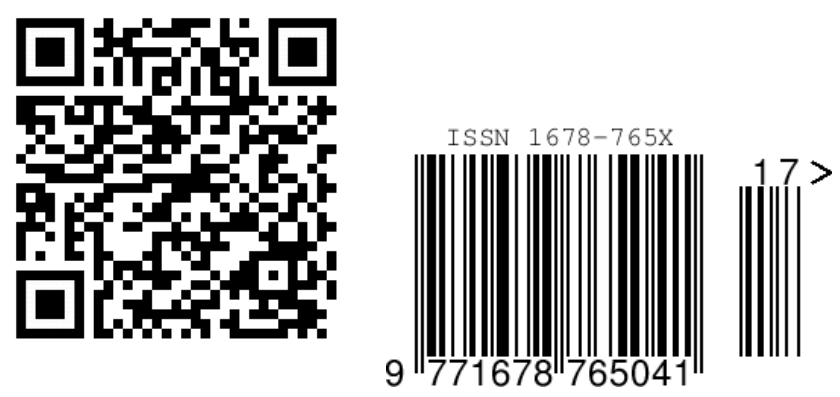

